Purdue University

Purdue e-Pubs

Purdue CIBER Working Papers

Krannert Graduate School of Management

$1-1-2003$

\title{
One minute in the life of the DM/US\$: public news in an electronic market
}

John A. Carlson

Purdue University

Melody Lo

University of Southern Mississippi

Follow this and additional works at: http:// docs.lib.purdue.edu/ciberwp

Carlson, John A. and Lo, Melody, "One minute in the life of the DM/US\$: public news in an electronic market" (2003). Purdue CIBER Working Papers. Paper 23.

http://docs.lib.purdue.edu/ciberwp/23

This document has been made available through Purdue e-Pubs, a service of the Purdue University Libraries. Please contact epubs@purdue.edu for additional information. 


\title{
One minute in the life of the DM/US\$: public news in an electronic market
}

\author{
John A. Carlson ${ }^{a} *$, Melody Lo ${ }^{b}$ \\ a Purdue University, Krannert School of Management, West Lafayette 47905, USA \\ ${ }^{\mathrm{b}}$ University of Southern Mississippi, Department of Economics, Hattiesburg 39402, USA
}

\begin{abstract}
Public news can be expected to change market prices but, unlike "public information," there are differing expectations about the full impact and hence trading is necessary for the market to process these divergent views. A good illustration of this is a surprise announcement of an increase in German interest rates coupled with remarkably detailed concurrent transactions data from an electronic market. After initial trades hollowed out the market, a large volume of seller-initiated trades removed most of the existing demand, without many of the prior bids being withdrawn. While this is contrary to a rationalexpectations view of public information, it is consistent with dealers' practice, as an exercise in self-discipline, to book targeted profits if possible in the face of uncertainty. Evidence also shows that the speculative activity by traders in reaction to the news destabilized the market for the next two hours.
\end{abstract}

JEL classification: F30; G14; G15

Keywords: Exchange rate; Public news; Public information; Electronic interdealer market; Order flows

* Corresponding author. Telephone: 765-494-4450; Fax: 765-494-9658; E-mail address: carlson@mgmt.purdue.edu 


\section{Public news and a notable price change}

On Wednesday, October 8, 1997, Alan Greenspan, Chairman of the U.S. Federal Reserve, testified before the House Budget Committee. He said labor trends suggest that the U.S. economy is on an unsustainable track ... continued rapid stock market gains are unrealistic, that inflation is likely to rise unless demand slows markedly and that productivity gains are unlikely to be enough to curb price pressures. These remarks suggested that the Fed might take a more active role in trying to temper stock market gains, possibly through higher U.S. interest rates, with a potential appreciation of the dollar.

The next day, Thursday, October 9, the Bundesbank had a council meeting to review its policy positions. Based on the fact that German unemployment remained at a high level of $11.2 \%$ in September and there was no major inflation threat at the time, the market consensus was for no immediate interest rate hike. Various presses repeatedly reported that the majority of traders expected no changes in interest rates that day, thinking it more likely to occur in a few weeks.

These expectations about the timing proved wrong. An 11:50 Greenwich Mean Time (GMT) AP-Dow Jones News reported: “At 1130 GMT, the Bundesbank announced that it had fixed the rate for its securities repurchase agreements at $3.30 \%$ for the next two weeks, up from $3.00 \%$. The German central bank said that the move had been aimed at preempting higher inflation, and will help damp growth in the M3 money supply aggregate. The dollar fell sharply following the Bundesbank announcement, hitting an intraday low of DM1.7428 just three minutes later, but by 1140 GMT had bounced to 
DM1.7450." This Bundesbank rate hike initiated an end to the five-year decline in European rates. ${ }^{1}$

For this particular Bundesbank interest-rate announcement, traders were not only surprised by the decision of an interest rate hike, but also by the unusual release time of 11:30 GMT. Hardy (1998) documents that the Bundesbank Council reviews its interest rates every other Thursday and decisions are announced later that afternoon or early the next morning. The press center of the Bundesbank confirms this claim and says that the most frequent timing for announcements is 3:00 in the afternoon (which would be 14:00 GMT). When the Bundesbank made its interest rate announcement on Oct. $9^{\text {th }} 1997$, the array of open orders appeared to be fairly normal. Thus, the unusual timing of unexpected news provides an opportunity to study precisely how traders react to a surprise announcement.

As is well known, in principle a price response to new public information can take place without any trades. According to Fleming and Remolona (1999, p. 1901), "Theory (e.g., French and Roll (1986)) identifies public information as that which affects prices before anyone can trade on it." In a foreign exchange market, this might happen when dealer quotes are only indicative and actual deals are struck over the telephone. If all dealers agree on a new market value after a public announcement, all prior quotes become obsolete. New quotes appear and trading can continue as usual around a markedly changed market price, without order flow during the change. This concept constitutes a standard simplification in the analysis of market microstructure that public information

\footnotetext{
${ }^{1}$ The English version of the press release is reproduced in an appendix along with a description of how the Bundesbank conveys its news to the public.
} 
does not affect the impact of concurrent order flows (see Hasbrouck (1991) as an example). Andersen, et al. (2003, p. 59) write that it will be of interest "to determine whether news affects exchange rates via order flow or instantaneously."

We will use the term public news for a situation in which there is uncertainty about the market impact of new information made available to all market participants at the same time. While we believe that the full impact of unexpected news will rarely be immediately assessed in the same way by all market participants, this terminology will avoid any potential confusion with the French and Roll concept of public information. When there is uncertainty about how much market price will change as the result of news, there will also be differing expectations. Trading then enables the market to sort out the net effect of the news.

The idea of divergent mappings from information to prices is discussed by Lyons (2001, p. 21) as one reason why order flow conveys information to the market and therefore tends to move price. He also quotes Isard (1995, pp. 182-3) who states that in view of "economist's very limited information about the relationship between equilibrium exchange rates and macroeconomic fundamentals, ... it is hardly conceivable that rational market participants with complete information about macroeconomic fundamentals could use that information to form precise expectations about the future market-clearing level of exchange rates." Isard's words aptly describe the situation that applies when we refer to an announcement of a change in fundamentals as public news.

In an electronic market, quotes are firm. If bids or offers are not canceled prior to or during a public announcement, transactions can occur as the price adjusts in reaction to 
new information. In the case of the surprise announcement by the Bundesbank on October 9,1997 , a huge volume of trading did occur in the minute of the announcement.

A notable change in behavior occurred at about 11:30:35, or 35 seconds after the announcement reportedly began. The transaction price of the dollar actually rose somewhat during the first 35 seconds and reached 1.7560 DM. Shortly after 11:30:35, however, the price of the dollar started to drop. At 11:30:59.03, there is a trade at 1.7450 DM. That is a drop of over 0.6 percent in 25 seconds. $[\ln (1.756)-\ln (1.745)=0.006284$.] To place the drop in perspective, consider what Dominguez (2003) found when she examined 5-minute returns in the DM/\$ rate from 1989 to 1995 . A return of 0.006284 would have been the ninth largest in that six-year period.

In this paper, we provide a detailed examination of data from an electronic market to study market reactions to this public news. Fig. 1 shows transactions prices for the $\mathrm{DM} / \$$ on the day of the announcement. The dashed line represents cumulative order flow. In the absence of public news, order flow, to be discussed in more detail below, generally drives prices in interdealer markets, such as the one depicted here. An upward move in price is associated with more buyer than seller initiated trades and a downward move with the opposite. Evans and Lyons (2002) have shown the strong short-term impact of order flow on exchange rates. In the case of the Bundesbank announcement, order flow turns out to play an extremely important role.

There is a literature examining the link between the arrival of news and market activity, measured by trading volume and price volatility. Berry and Howe (1994) and Mitchell and Mulherin (1994) are such studies with a focus on a stock market, while Melvin and Yin (2000) deal with a foreign exchange market. We complement this 
literature by an analysis of market activity in an electronic foreign exchange market as the result of a speculative activity by traders in response to a surprise macro announcement.

In what follows, section 2 describes some remarkably detailed data and the nature of an electronic interdealer market. There are two distinct phases of trading activity in the first minute after 11:30. The first phase, lasting about 35 seconds and described in section 3 , is a flurry of trades and a hollowing out of the market, a strong indication of uncertainty about the pending announcement.

The second phase, discussed in section 4 , is a large drop in the dollar as sellers rapidly hit existing demand. What is surprising here is how little of the demand was withdrawn during this period.

The speculative trading that took place during that first minute set in motion subsequent dynamics, which are discussed in Section 5. In the second minute after the announcement, something occurs that is quite contrary to the idea that price adjusts without trades or order flow when there is new public information. In this case, order flow was strongly negative throughout the second minute and yet price changed very little. We offer an explanation that is consistent with the uncertainties generated by public news and the prior speculative trading. Section 5 also reports evidence that it took about two hours before the market again settled into more normal patterns. Section 6 concludes.

\section{An electronic interdealer FX market}

The interdealer market data we will analyze come from what is known as the D2000-2 electronic market, maintained by Reuters. The data for the week of October 6 10, 1997, for trading of the DM/\$ were obtained from Reuters by the Financial Markets 
Group at the London School of Economics. See Goodhart, et al. (1996), and Danielsson and Payne (2002) for additional details about the D2000-2 data.

At any time, a participating dealer can enter:

A bid, a limit order to buy at a specified price or lower, An ask, a limit order to sell at a specified price or higher, A hit, a market sell order at the best available bid price, or A take, a market buy order at the best available ask price.

The dealer can also withdraw or cancel an unfilled bid or ask. The system records actual transactions and keeps track of all the existing orders that have not been filled. The screen that the dealers see shows only the highest bid, the lowest ask, the quantities available at these best bid and ask prices, and the price of the most recent transaction. The data show to the nearest 0.01 of a second the times when a transaction enters the market and when it is removed or withdrawn.

An interdealer FX market provides a link between diverse buyers and sellers of foreign exchange. For ease in exposition we will often refer to a bank's dealing room as the bank and, while several people may be involved, we will occasionally refer to a single trader carrying out different transactions and representing the fiduciary interests of the bank. See Lyons (2001) for a detailed discussion of the microstructure approach to exchange rates.

Portfolio shifts and changing needs for different currencies by banks' customers are an ongoing process. Customers may deal regularly with one bank or may check with several banks for the best prices before placing an order. A bank will typically quote both bid and ask prices in response to a query and the caller may or may not choose to buy 
foreign currency at the bank's ask price or sell at the bank's bid price. These quotes will change over time in response to market changes and may be different for different types of customers. There are now electronic broking systems for these customer markets that did not exist in 1997.

For illustrative purposes, suppose the bank offers to sell dollars at $1.7520 \mathrm{DM} / \$$ and to buy at $1.7510 \mathrm{DM} / \$$. Consider what might happen if a customer decides to buy 2 million dollars with DM at a price of 1.7520. This is an example of what is known as private information in the literature. In this case, the bank is now long in DM and short in dollars and needs to decide what to do. A trader for the bank can put in a market take order in the interdealer market to buy dollars right away. Or the trader can speculate by putting in a limit bid order to buy dollars at a price below the current best offer price in the market.

A decision to cover the bank's position and buy dollars immediately in the interdealer market is profitable for the bank because the "touch" or "inside spread", the difference between the lowest offer price and the highest bid price, is typically smaller than the spread in the customer market. Suppose, for example, that the best offer price is 1.7516 and the best bid price is 1.7514 . If the bank buys 2 million dollars at 1.7516 , there is an immediate profit of $800 \mathrm{DM}(\$ 2,000,000$ times $0.0004 \mathrm{DM} / \$)$.

As evident in Fig. 1, the market price jumps around. If instead of immediately covering the bank's short position in dollars, the bank's trader puts in a bid price to buy 2 million dollars at a price below 1.7516 , say 1.7514 , and waits for another dealer to agree to sell 2 million at the limit price, this is a speculative position. The market may hit the price and the profit is 1,200 DM. However, there may be a subsequent run of buyer-initiated 
trades, and the trading prices may start to rise. In setting a limit order, the trader has to weigh the tradeoff between the expected gain from waiting and the greater uncertainty about the eventual price at which the bank's position is covered. ${ }^{2}$

Our example of a bank receiving an order from a customer to purchase 2 million dollars is, as noted above, private information. If the bank immediately covers the position in the interdealer market by making a purchase of dollars, this is known as a positive order flow and in effect transmits to the market the bank's private information. An order flow is a signed transaction in the interdealer market. If a buyer initiates a trade, the order flow is positive. If a seller initiates a trade, the order flow is negative. Over a period of time, the net order flow is the difference between the quantity of buyer-initiated and seller-initiated trades in the interdealer market.

Since all transactions in this interdealer market are in millions of dollars, in later discussion we will refer to the transactions in units, where it is understood that one unit is one million dollars.

\section{The market while the announcement is pending}

At any time in the interdealer market, there is an array of limit orders to buy and an array of limit orders to sell. We will refer to unfilled buy orders as demand in the interdealer market and to unfilled sell orders as supply. Fig. 2 depicts the situation at 11:30 am on Thursday, October 9,1997 . At precisely 11:30 am the highest buy order was at $1.7530 \mathrm{DM}$ for 5 units. The relatively flat demand schedule depicted in Fig. 2 is the

\footnotetext{
${ }^{2}$ Costs and benefits of placing orders rather than dealing immediately are discussed in Handa and Schwartz (1996), Foucault (1999), and Hollifield et al. (2002), inter alia.
} 
cumulative array of limit buy orders unfilled as of 11:30. These consist of the 5 units at $1.7530,1$ unit at $1.7523,2$ units at 1.7522, 2 units at 1.7521, and on down. The supply schedule is the cumulative array of limit sell orders: 5 units at $1.7535,1$ unit at $1.7538,2$ units at $1.7539,3$ units at 1.7542 and on up. The degree of liquidity in the market is reflected in both the inside spread and the flatness of the curves. For the picture shown, the inside spread is 0.0005 , and the spread at 10 units is $0.0021(=1.7542-1.7521)$. These spreads were somewhat more than was typical for this market during active hours, but not unusually so. (See Danielsson and Payne (2002) for a distribution of inside spreads during the week and footnote 4 below.) The picture is one of fairly strong buying support for the dollar at this time.

When the announcement by the Bundesbank reportedly began at 11:30, there are no trades for the next 13 seconds and 6 units of sell offers are withdrawn. The absence of trades suggests that dealers temporarily stopped trading to note that an announcement was pending.

Over the next 22 seconds, from 11:30:13 to 11:30:35, there is a large volume of activity. About 87 units are traded. These are both supply initiated and demand initiated, and the price trend is generally up during these 22 seconds, rising from 1.7530 to 1.7560 . The fact that the transactions prices rose indicates that many traders did not yet expect that the news would precipitate a fall in the dollar.

Fig. 2 shows considerably more demand than supply at 11:30:00. We interpret this as indicative of a greater volume of open short positions in dollars than open long positions in the interdealer market. The increase in the price of the dollar during those 35 seconds 
undoubtedly represents more short covering by buyer-initiated trades at the best offer prices than long covering by seller-initiated trades at the best bid prices during this period.

As a result of this activity, there is a substantial hollowing out of the market from 11:30:00 to 11:30:35. This can be seen by comparing Fig. 2 and Fig. 3. By 11:30:35, the inside spread grew to 0.0039 and the spread at 10 units to 0.0052 . These are very large for this market. Some dealers evidently covered speculative positions and were waiting to see how to interpret the news.

\section{A dramatic shift in trading activity}

The full impact of the announcement hits the market at about 11:30:35. As seen by comparing Fig. 3 and Fig. 4, there is a dramatic shrinkage of the demand curve between 11:30:35 and 11:31:00. Beginning at 11:30:37 until 11:30:59, sellers rapidly hit buy orders along the demand curve, mostly by crossed limit orders rather than by market orders. ${ }^{3}$ During that time, the price falls to 1.7450 .86 units along the demand curve that existed at 11:30:35 are removed. Remarkably, only 5 of these units were removed by bidders withdrawing their bids. All the rest were seller-initiated trades.

During these 25 seconds, there is also considerable activity by sellers testing the market. If an offer does not immediately result in a transaction, many of these offers are withdrawn within a few seconds. A comparison of Fig. 3 and Fig. 4 shows a few new

\footnotetext{
${ }^{3}$ A market sell order trades at the best available bid price. In a rapidly changing market, there is uncertainty about what the transaction price may be. A limit order to sell below existing bid prices will transact at any bid prices above the limit order, up to the quantity specified, but assures that the selling price will not be below the limit price.
} 
offers that entered between 11:30:35 and 11:31 are still on the supply side of the market. All of the unfilled offers as of 11:30:35 are eventually withdrawn without any sale.

In this electronic market, because buy orders were not withdrawn quickly, negative order flow drove the price lower. By 11:30:35, many dealers, contrary to prior expectations, expected the DM price of the dollar to fall. If that had been fully anticipated, there would not have been such a high and flat demand curve at that time.

An interesting question is why more of the demand was not immediately withdrawn after 11:30:35. To address this question, we need to distinguish limit orders by whether or not they represent speculative cover for open positions. Some dealers may, at that moment, be market makers without a long or short position. Their limit orders have been entered in hopes of making profits by eventual transactions on both sides of their spread. When new information arrives suggesting that the market price will fall, their bids should be immediately withdrawn and new bids entered at a lower price, although these dealers may wait to see where the market stabilizes before entering new bids. There is less urgency about immediately replacing their ask prices in this situation. The fact that so few units of demand were withdrawn as the price fell suggests that there were very few market makers without open positions among the higher bid prices at 11:30:35.

From this we infer that most of the bids at the top of the demand curve were put in by dealers with short positions in dollars. Their bid prices, if executed, would yield a profit to the bank. The question then is why these dealers did not withdraw their bids, which were based on prior information, and put in new lower ones to reap extra expected profits. Since these bids represent speculative cover of open positions that are the result of prior sales of dollars, the fall in the price of the dollar is good news for these traders whose 
bids can shortly be executed if not withdrawn. If they get greedy, withdraw their existing bids, and try to buy later at a lower price, they may miss a turning point and not realize the profit at all. As an exercise in self-discipline, which is essential for success, dealers let targeted profitable bids be hit. Conversations with dealers indicate that this is a common practice, and in a practitioner's guide for currency traders, Henderson (2002, p. 189) stresses: "Trading discipline is at least as important as having the right view."

For reasons of confidentiality, individual dealers are not identified in the data set, so we cannot tell if dealers whose prior bids were hit also tried to make sales to other bidders. There is no reason why they cannot join the crowd and make speculative sales if they think additional expected profits are possible.

These considerations raise another point. While order flow drives the market price given the existing limit orders, the source of the order flow can make a difference. Dealerdriven order flow can have implications for subsequent market behavior that differ from customer-driven order flow. When a seller-initiated transaction in the interdealer market covers a bank's prior sale to a customer, the bank's position has been squared and there is no subsequent potential trading because of that transaction. By dealer-driven order flow, we mean speculative open positions taken by dealers. At some point those dealers will need to cover their positions and that can induce further uncertainty and volatility in the market. Thus, we expect subsequent effects well after the Bundesbank announcement.

\section{Time to settle down}


To begin an examination of the subsequent dynamics, we take a closer look at the patterns of order flow and price changes during the two minutes after 11:30. Fig. 5 shows cumulative order flow and transaction prices from 11:30 to $11: 32 .{ }^{4}$

As can be seen in Fig. 5, the pattern during the first minute is definitely one of order flow driving price. The relatively big drop in price right after 11:30:35 was a bounce from a prior buyer-initiated trade along the existing supply schedule to a seller-initiated trade along the then much lower demand schedule.

At first glance, the second minute looks anomalous. Order flow continued to be strongly negative but this did not drive price lower. There were trades at a price of 1.7450 $\mathrm{DM} / \$$ at 11:31:01.06 and again a minute later at 11:32:01.60. In between, price bounced up occasionally but never very far above 1.7450 . The negative flow is generated by the fact that dealers were putting in new buy orders that were almost immediately hit by sellerinitiated trades. It is likely that these new buy orders were by dealers who had made speculative sales during the price decline in the first minute. It looked as if a temporary floor had been found, so they were booking their profit from the prior speculative sales.

The fact that there were also willing sellers at this price level reflects still divergent views about when the price will stop falling. The evidence suggests the following scenario. Some customers, who continuously monitor the market, decide to sell dollars. This will give rise to customer-driven order flow in the interdealer market. The banks receiving these orders have private information about selling pressure that they believe will drive price still lower in the interdealer market. The dealers in these banks therefore want

\footnotetext{
${ }^{4}$ This differs from Fig. 1 in two ways. First, Fig. 5 shows tick-by-tick data while Fig. 1 is accumulated over 5 second intervals and the price is the last transaction price during the interval. Second, in Fig. 5 order flow is
} 
to cover their long positions immediately by selling dollars in the interdealer market. Some may also take speculative short positions. Thus, the decline in price in the first minute could have been in anticipation of customer-driven order flow that would follow in the second minute or later. For price to decline further then depends on ensuing decisions by customers to sell dollars.

For the next two hours, with lots of bounces, the trend in price is down and order flow is negative. Over time, as dealers try to square their positions, their purely speculative order flows should tend to cancel each other. Therefore, a negative net order flow over a period as long as two hours is very likely generated by outside customer sell orders. In that case, the picture in Fig. 1 indicates that somewhat delayed portfolio shifts out of dollars and into DMs drove the price of the dollar down.

This downward pressure on the dollar then drew central banks into the market. According to an AFX news wire at 14:03 GMT: "A number of European central banks, among them the Bundesbank, are reported by dealers to have been intervening in the currency market in an effort to cap the strength of the mark following the decisions to raise German and other core European interest rates, dealers said. They said that central banks have been buying dollar/mark just below the 1.7400 level.”

In Fig. 1, the downward trend in the price of the dollar is reversed by about 13:30. In addition to central bank demands for dollars, outside sellers of dollars are probably buying them back. By the end of the day, the dollar has recovered to its level reached shortly after the announcement.

weighted by the size of a transaction, and in Fig. 1 order flow is unweighted. 
Evidence indicates that it took about two hours for trading volume and price volatility to settle down to normal in this market. Table 1 records mean trading volumes per minute in 10 minute intervals from 11:00 to 14:00 on Thursday and on Monday, Tuesday and Wednesday, as well as $p$-values for the hypotheses of equal means. Between 11:10 and 11:30 on Thursday, volume was slightly less than on the prior three days but not significantly so. As we detailed above, volume rose dramatically during and immediately after the announcement on Thursday, and significantly so compared with Monday through Wednesday. Volume remained relatively high on Thursday until about 13:20.

For eight different hours of the day, Monday through Thursday from 7:30 to 15:30 GMT, for a total of 1920 minutes, average trading volume was 19.7 million dollars per minute with a standard deviation of 17.7. The high standard deviation relative to the mean reflects a few large outliers and a strong positive skewness of 2.5. In those 1920 minutes, over half of the minutes with the largest 1 percent of total volume occurred on Thursday within two hours after the announcement.

A similar story about the continuing effects of the surprise announcement can be seen in data on price volatility, shown in Table 2. Price volatility is measured by the average absolute values of the log change in end-of-minute prices. Thursday's volatility jumps to exceed an average level of Monday, Tuesday and Wednesday substantially for the 30 minutes following the announcement and remains relatively high until at least 13:40. Of the 19 highest absolute values of log price changes on those four days, 14 or them occurred within two hours after the announcement on Thursday and 11 of them within the first half hour. The story is much the same in terms of within minute price volatility. 
One other way of assessing market reactions to the news is to examine the spreads between the supply and demand curves, such as those depicted in Fig. 2 through Fig. 4. Table 3 shows the inside spread and spreads at 10 and 40 units at various times on Thursday. While the inside spread remains fairly narrow after 11:40, there is an occasional widening at higher numbers of units. By 13:10 a fairly normal depth to the market appears to have been reestablished, although the spreads are still somewhat higher than for comparable times on Monday, Tuesday and Wednesday. ${ }^{5}$ A figure for demand and supply curves at 13:20, is very much like the one at 11:30 shown by Fig. 2, albeit at lower prices.

\section{Concluding remarks}

An announcement of an interest-rate increase by the Bundesbank beginning at 11:30 Thursday, October 9, 1997, is a good example of public news, in which uncertainty about the impact results in substantial trading. It contains news that had evidently not been anticipated at that time and therefore, together with a concurrent record of transactions in an electronic $\mathrm{DM} / \$$ market, provides an opportunity to analyze in detail dynamic market responses to news. Portfolio balance models predict that this should cause an immediate appreciation of the DM, as portfolio managers try to switch from dollar to DM assets, but no one knows for sure how much appreciation will occur.

The first to react to such public news will be the traders in the interdealer market. If existing price quotes are all indicative and if there is a consensus on what the new price

\footnotetext{
${ }^{5}$ For example, a sampling of spreads between 13:00 and 14:00 on Monday, Tuesday and Wednesday yields are average inside spread of 2.0, an average spread at 10 units of 7.4 and an average spread at 40 units of 41.4 .
} 
should be, then the DM/\$ price can in principle drop immediately without any trading (the French and Roll (1986) view of public information).

By contrast, in the case of the Bundesbank's interest-rate announcement, the initial reaction is an extremely high volume of trading, both supply and demand initiated, and an increasing spread as some traders presumably cover speculative positions. After 11:30:35, there begins a huge volume of seller initiated trades (negative order flow) along much of the existing demand schedule.

When most market participants believe that the price of the dollar is about to drop, there is obviously no immediate need to cancel high sell orders. However, dealers who are long in dollars will have an urgency to sell quickly or risk losses on their positions. Hence they rush in to sell at existing bid prices.

The news that the dollar will drop is good news for dealers who are short in dollars and have open bids to buy dollars. Their choice is either (1) to withdraw their bids and wait until the price does drop or (2) to let the market hit their bids, book their profits, and perhaps speculate with sell orders of their own. The fact in this instance that very few bids were withdrawn indicates that dealers with short positions in dollars overwhelmingly chose the second option. This is consistent with a practice by dealers, as an exercise in self discipline, to book profits targeted by the original bids in the face of continuing uncertainty about price changes.

These considerations lead us to hypothesize that, in a reverse situation in which public news suddenly calls for the appreciation of the currency being traded, offers in an electronic market will be taken more quickly by eager buyers than existing sell orders will be withdrawn. 
We also attribute the continued high volume and price volatility of the $\mathrm{DM} / \$$ after 11:31 on Thursday, October 9, 1997, to the speculative activity just prior to 11:31. Except for those who were covering long positions in the dollar, dealers who sold as the price was dropping now have short positions. They represent a base of support as dealers try to decide when to square their positions. As dealers adjust positions, waves of trades and price bounces can readily follow.

From evidence in the D2000-2 data, it took about two hours after the announcement before the market settled down from the dealer generated speculative activity. Some of the extra volume after 11:31 can be the result of outside desired portfolio shifts and central bank interventions, but the extra price volatility is very likely generated by dealer speculation.

One last point to emphasize is that in a real-time electronic market, everyone does not react at once to news. First movers can influence the subsequent dynamics. In the case of the German interest rate announcement in October 1997, speculative selling hit existing demand in the interdealer market faster than demand was withdrawn and well before outside portfolio shifts could be implemented. 


\section{Appendix: The Bundesbank press release of Oct. $9^{\text {th }}, 1997$}

The Bundesbank holds a press conference and gives out press-releases in both German and English versions after each meeting of the Central Bank Council. The Bundesbank does not broadcast its announcement but radio, TV, and news-wire reporters are invited to attend the press conference. News agencies would immediately convey the official announcement to their stations and the news is then transmitted to the dealing room. The English version of the press release reads as follows:

"At its meeting today, the Central Bank Council of the Deutsche Bundesbank decided to raise the fixed rate of interest for its securities repurchase agreements (repos) on October 15 and 22, 1997 from hitherto $3.00 \%$ to $3.30 \%$.

"The Central Bank Council gave the following explanation for the move:

"The Bundesbank has been pursuing an expansionary monetary policy for a considerable time now. On balance, the central bank interest rates have been at historically low levels since the interest rate cuts in April and August 1996. Money balances grew sharply in 1996 and at the beginning of 1997 . Owing to the weakening of the external value of the Deutsche Mark so far this year, monetary conditions have eased further.

"A concurrent shift has occurred in the monetary policy setting. The price climate changed during the summer months. Import prices, producer prices and consumer prices have all risen. This was due in large part to exchange rate movements against the US dollar and to increases in administered prices.

"To date, falling unit labour costs have acted as counterweight to "imported" and administered price stimuli. Hence there is no cause to dramatise the current price trend. The risks to price stability have increased, however. Timely countermeasures improve the 
prospects of steadying the growth process and prevent the build-up of an inflation potential in the run-up to European monetary union.

"In keeping with its statutory mandate and within the framework of its monetary policy options, the Bundesbank must endevour to ensure, above all, that the provision of liquidity to the economy offers no leeway for an acceleration in the upward trust of prices. In order to safeguard this for the future, a further deceleration of monetary growth is called for - as the Central Bank Council pointed out already in July in its review of the monetary target. This slight tightening of monetary policy associated with the raising of the repo rate is intended to serve that purpose." 


\section{References}

Andersen, T. G., Bollerslev, T., Diebold, F. X., Vega, C., 2003. Micro effects of macro announcements: real-time price discovery in foreign exchange. American Economic Review 93, 38-62.

Berry, T. D., Howe M. K., 1994. Public information arrival. Journal of Finance 49, 13311346.

Danielsson, J., Payne, R., 2002. Real trading patterns and prices in spot foreign exchange markets. Journal of International Money and Finance 21, 203-222.

Dominguez, K. M., 2003. The market microstructure of central bank intervention. Journal of International Economics 59, 25-45.

Evans, M. D. D., Lyons, R. K., 2002. Order flow and exchange rate dynamics. Journal of Political Economy 110, 170-180.

Fleming, M. J., Remolona, E. M., 1999. Price formation and liquidity in the U.S. treasury market: the response to public information. Journal of Finance 54, 1901-1915.

Foucault, T., 1999. Order flow composition and trading costs in a dynamic limit order market. Journal of Financial Markets 2, 99-134.

French, K., Roll, R., 1986. Stock return variances: the arrival of information and the reaction of traders. Journal of Financial Economics 17, 5-26.

Goodhart, C., Ito, T., Payne, R., 1996. One day in June 1993: a study of the working of the Reuters 2000-2 electronic foreign exchange trading system. In Frankel, J. A., Galli, G., Giovannini, A., (Eds.), The Microstructure of Foreign Exchange Markets. University of Chicago Press, pp. 107-179.

Handa, P., Schwartz, R. A., 1996. Limit order trading. Journal of Finance 51, 1835-1861. 
Hardy, D. C., 1998. Anticipations and surprises in central bank interest rate policy: the case of the Bundesbank. IMF Working Paper No. 98/43.

Hasbrouck, J., 1991. Measuring the information content of stock trades. Journal of Finance, 179-207.

Henderson, C., 2002. Currency Strategy: The Practitioner's Guide to Currency Investing, Hedging and Forecasting. John Wiley \& Sons.

Hollifield, B., Miller, R., Sandas, P., Slive, J., 2002. Liquidity supply and demand in limit order markets. Rodney White Center for Financial Research Working Paper, University of Pennsylvania.

Isard, P., 1995. Exchange Rate Economics. Cambridge University Press.

Lyons, R. K., 2001. The Microstructure Approach to Exchange Rates. MIT Press.

Melvin, M., Yin, X., 2000. Public information arrival, exchange rate volatility and quote frequency. The Economic Journal 110, 644-661.

Mitchell, M. L., Mulherin, J. H., 1994. The impact of public information on the stock market. Journal of Finance 49, 923-950. 


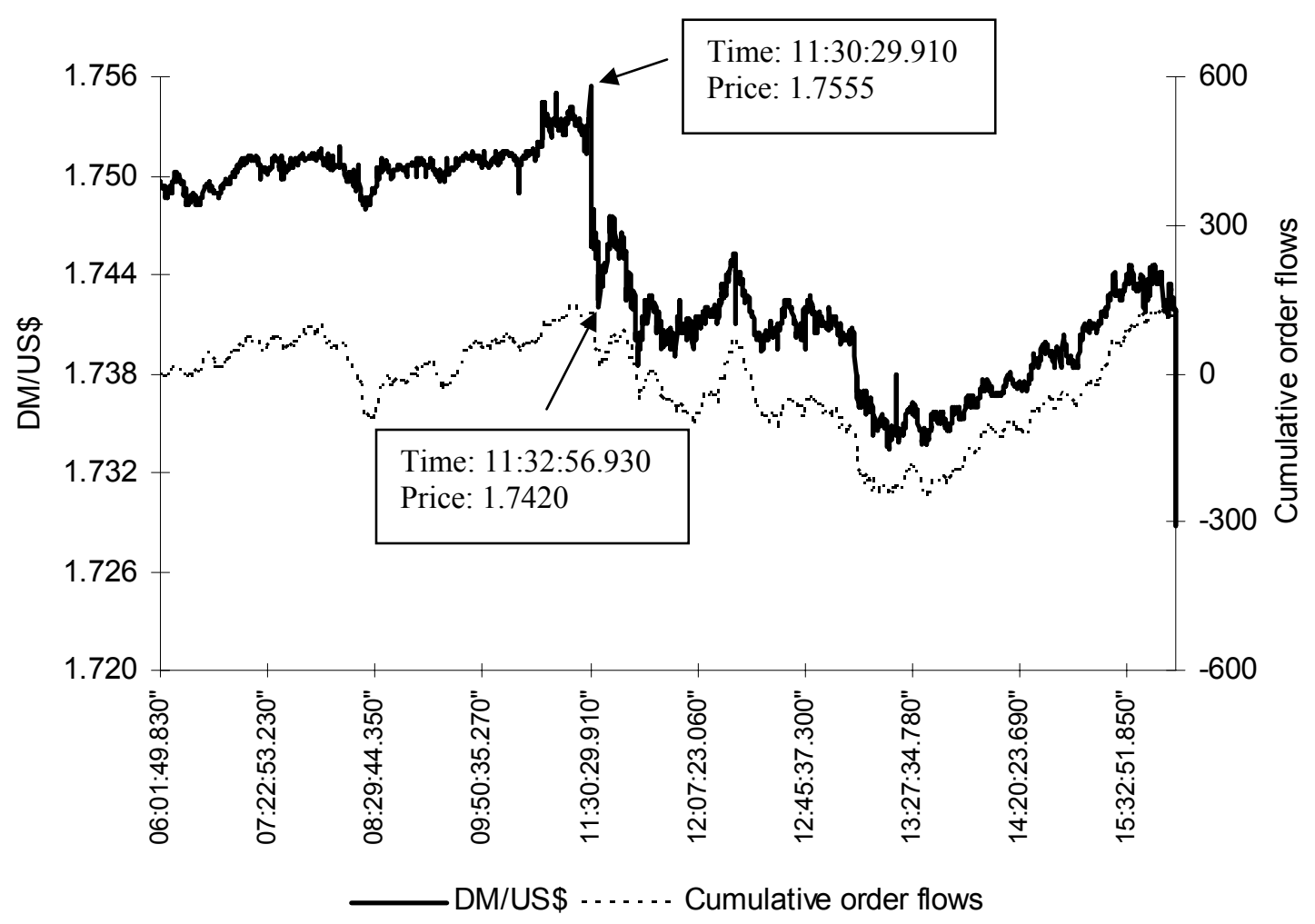

Fig. 1. The price of DM/US\$ and cumulative order flows for Thursday of Oct. $9^{\text {th }}, 1997$ 


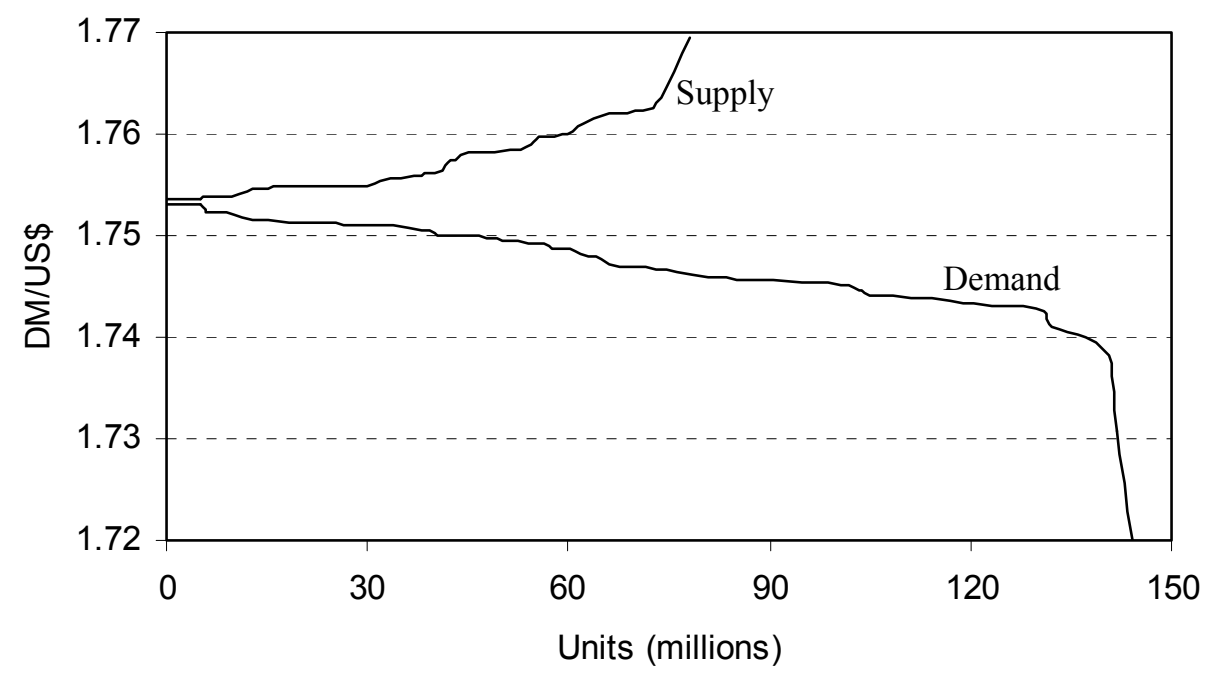

Fig. 2. Demand and supply at 11:30:00, Thursday

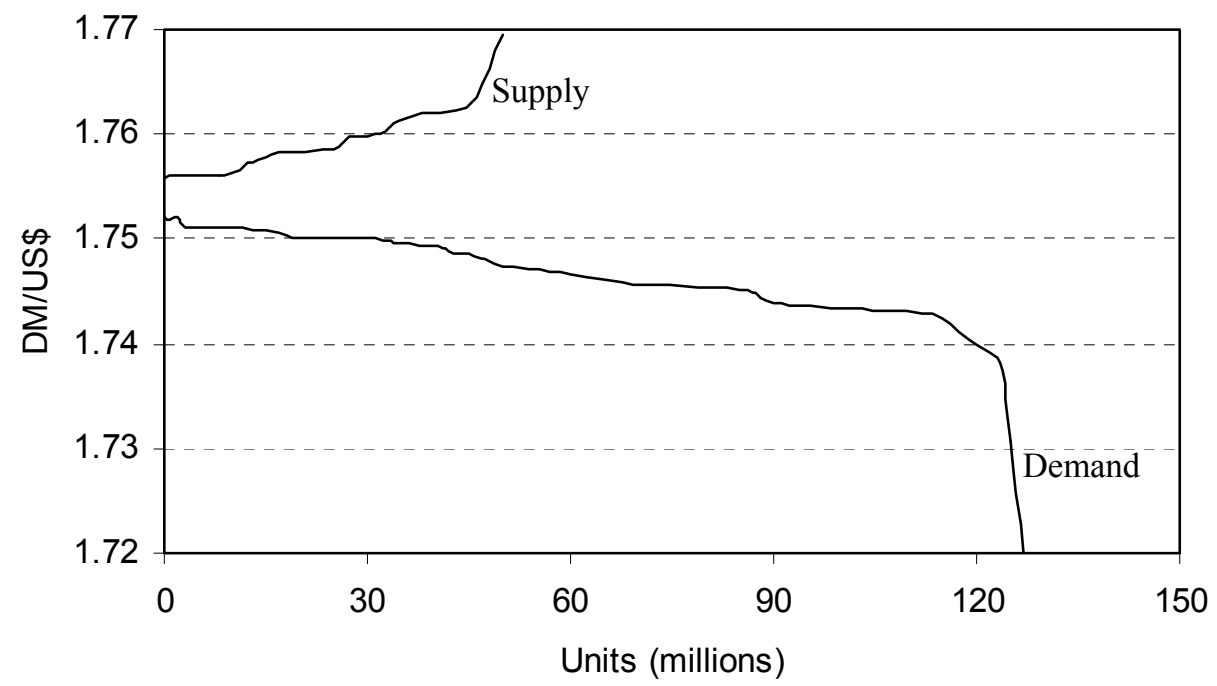

Fig. 3. Demand and supply at 11:30:35, Thursday 


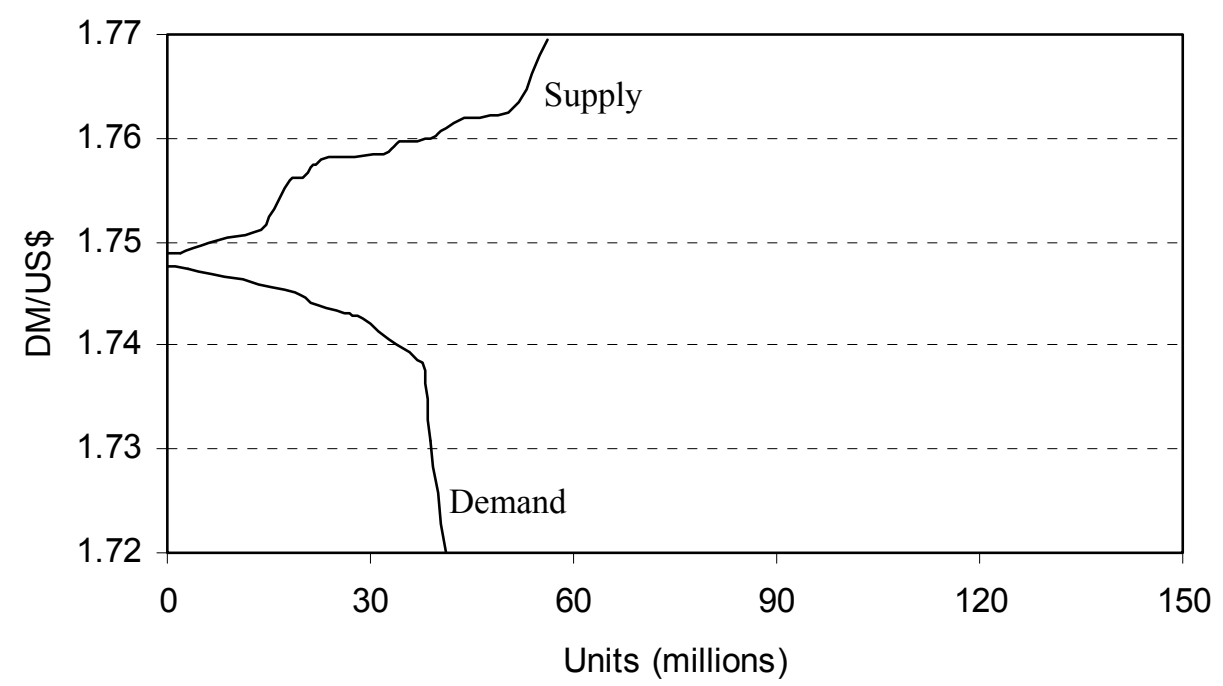

Fig. 4. Demand and supply at 11:31:00, Thursday

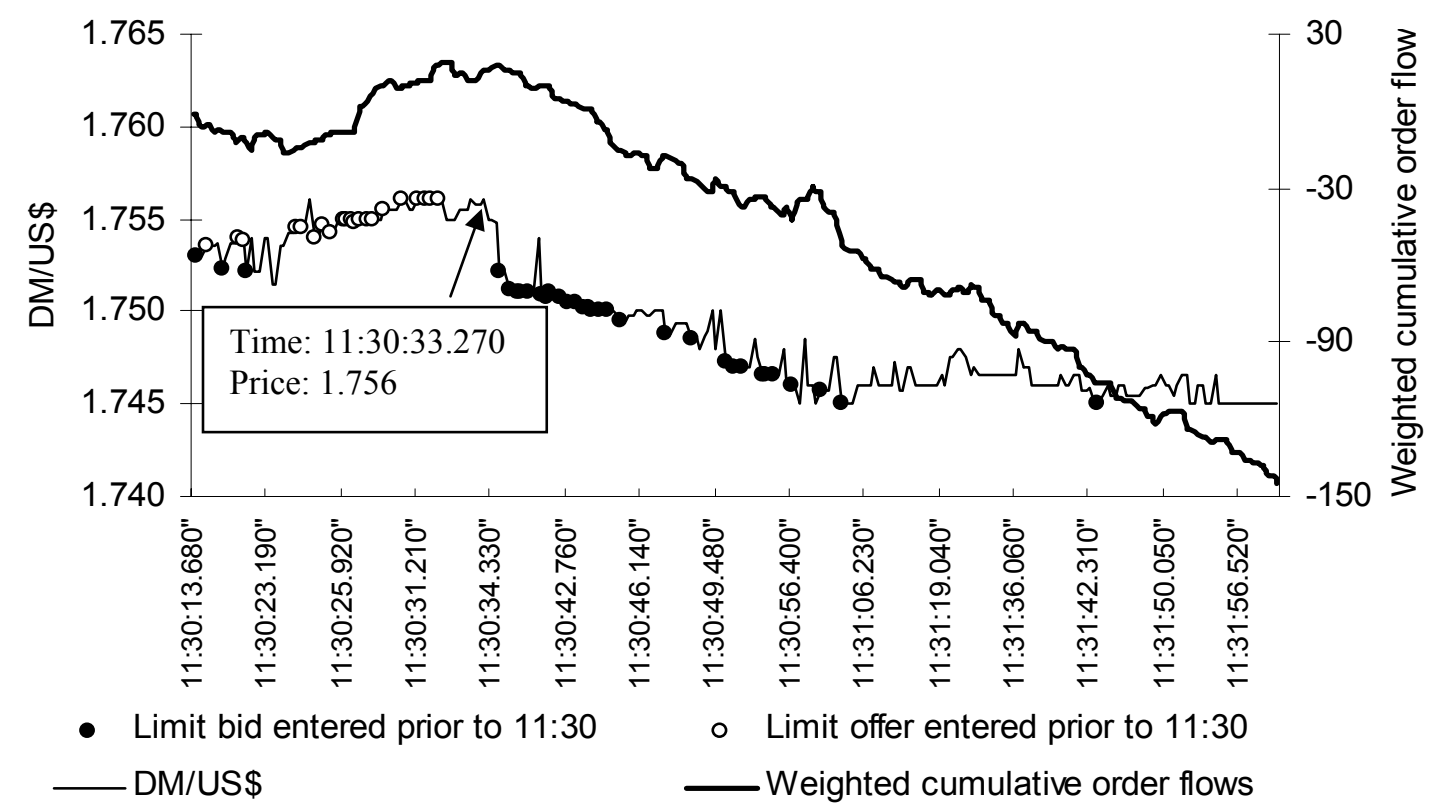

Fig. 5. The price of DM/US\$ and weighted cumulative order flows for Thursday 11:30$11: 32$. 
Table 1

Average per-minute trading volumes: Thursday vs. Monday, Tuesday and Wednesday ${ }^{\mathrm{a}}$

\begin{tabular}{lcccccc}
\hline Interval & $11: 00-11: 10$ & $11: 10-11: 20$ & $11: 20-11: 30$ & $11: 30-11: 40$ & $11: 40-11: 50$ & $11: 50-12: 00$ \\
& & & & & & \\
\hline Thur. & 19.750 & 13.250 & 12.050 & 82.350 & 67.300 & 40.300 \\
Mon.-Wed. & 17.167 & 15.667 & 18.267 & 16.750 & 17.933 & 15.967 \\
Difference & 2.583 & -2.417 & -6.217 & $65.600^{* * *}$ & $49.367 * * *$ & $24.333^{* * *}$ \\
{$[p$-value] } & {$[0.685]$} & {$[0.458]$} & {$[0.115]$} & {$[0.001]$} & {$[0.001]$} & {$[0.002]$} \\
\hline Interval & $12: 00-12: 10$ & $12: 10-12: 20$ & $12: 20-12: 30$ & $12: 30-12: 40$ & $12: 40-12: 50$ & $12: 50-13: 00$ \\
& & & & & & \\
Thur. & 24.750 & 38.350 & 48.400 & 35.200 & 28.150 & 17.500 \\
Mon.-Wed. & 11.550 & 16.967 & 34.433 & 18.050 & 27.967 & 21.733 \\
Difference & $13.200 * * *$ & $21.383 * *$ & $13.967 *$ & $17.150 * *$ & 0.183 & -4.233 \\
[p-value] & {$[0.001]$} & {$[0.013]$} & {$[0.085]$} & {$[0.023]$} & {$[0.971]$} & {$[0.280]$} \\
\hline Interval & $13: 00-13: 10$ & $13: 10-13: 20$ & $13: 20-13: 30$ & $13: 30-13: 40$ & $13: 40-13: 50$ & $13: 50-14: 00$ \\
& & & & & & \\
Thur. & 44.950 & 55.100 & 25.050 & 21.050 & 19.700 & 24.750 \\
Mon.-Wed. & 28.583 & 28.717 & 23.367 & 22.533 & 22.117 & 23.700 \\
Difference & 16.367 & $26.383 * * *$ & 1.683 & -1.483 & -2.417 & 1.050 \\
{$[p$-value] } & {$[0.359]$} & {$[0.001]$} & {$[0.623]$} & {$[0.726]$} & {$[0.505]$} & {$[0.840]$} \\
\hline
\end{tabular}

${ }^{\mathrm{a}}$ Unequal variances are assumed when testing the hypotheses of equal means. Also, *,**, and $* * *$ denote $10 \%, 5 \%$ and $1 \%$ significant levels respectively. 
Table 2

Last trade price volatility comparisons: Thursday vs. average of Monday, Tuesday and Wednesday ${ }^{\mathrm{a}}$ Interval $\quad 11: 00-11: 10 \quad 11: 10-11: 20 \quad 11: 20-11: 30 \quad 11: 30-11: 40 \quad 11: 40-11: 50 \quad 11: 50-12: 00$

\begin{tabular}{lcccccc}
\hline Thur. & 1.264 & 0.916 & 1.239 & 4.650 & 3.042 & 2.096 \\
Mon.-Wed. & 0.677 & 0.470 & 0.801 & 0.726 & 0.643 & 0.586 \\
Difference & 0.587 & $0.446^{* *}$ & 0.438 & $3.924 *$ & $2.399^{* * *}$ & $1.510^{* *}$ \\
{$[p$-value $]$} & {$[0.220]$} & {$[0.026]$} & {$[0.191]$} & {$[0.052]$} & {$[0.004]$} & {$[0.019]$} \\
\hline Interval & $12: 00-12: 10$ & $12: 10-12: 20$ & $12: 20-12: 30$ & $12: 30-12: 40$ & $12: 40-12: 50$ & $12: 50-13: 00$ \\
& & & & & & \\
Thur. & 0.873 & 0.897 & 1.321 & 0.848 & 1.471 & 1.497 \\
Mon.-Wed. & 0.454 & 0.627 & 0.636 & 0.479 & 0.578 & 0.429 \\
Difference & 0.419 & 0.270 & 0.685 & $0.369^{* *}$ & $0.894 * *$ & $1.067 * *$ \\
{$[p$-value $]$} & {$[0.226]$} & {$[0.393]$} & {$[0.065]$} & {$[0.046]$} & {$[0.006]$} & {$[0.048]$} \\
\hline Interval & $13: 00-13: 10$ & $13: 10-13: 20$ & $13: 20-13: 30$ & $13: 30-13: 40$ & $13: 40-13: 50$ & $13: 50-14: 00$ \\
& & & & & & \\
Thur. & 1.573 & 1.652 & 1.001 & 1.227 & 0.826 & 0.850 \\
Mon.-Wed. & 1.014 & 0.569 & 0.560 & 0.634 & 0.552 & 0.577 \\
Difference & 0.560 & $1.083^{* *}$ & $0.441^{* *}$ & $0.592^{*}$ & 0.274 & 0.274 \\
{$[p$-value $]$} & {$[0.454]$} & {$[0.027]$} & {$[0.020]$} & {$[0.061]$} & {$[0.208]$} & {$[0.293]$} \\
\hline
\end{tabular}

${ }^{\mathrm{a}}$ Unequal variances are assumed when testing the hypotheses of equal means. Also, *,**, and $* * *$ denote $10 \%, 5 \%$ and $1 \%$ significant levels respectively. 
Table 3

Spreads between supply and demand curves on Thursday ${ }^{\mathrm{a}}$

\begin{tabular}{lccccccc} 
Time & $11: 29$ & $11: 30$ & $11: 31: 35$ & $11: 31$ & $11: 35$ & $11: 40$ & $11: 45$ \\
& & & & & & & \\
\hline Inside Spread & 3 & 5 & 39 & 15 & 4 & 1 & 3 \\
Spread at 10 units & 18 & 21 & 52 & 62 & 4 & 10 & 40 \\
Spread at 40 units & 64 & 60 & 132 & 405 & none & 179 & none \\
\hline Time & $11: 50$ & $12: 00$ & $12: 10$ & $12: 20$ & $12: 30$ & $12: 40$ & $12: 50$ \\
& & & & & & & \\
\hline Inside Spread & 3 & 2 & 1 & 3 & 3 & 1 & 1 \\
Spread at 10 units & 14 & 23 & 10 & 6 & 11 & 9 & 4 \\
Spread at 40 units & 70 & 80 & 26 & 50 & 75 & 72 & 45 \\
\hline Time & $13: 00$ & $13: 10$ & $13: 20$ & $13: 30$ & $13: 40$ & $13: 50$ & $14: 00$ \\
& & & & & & & \\
\hline Inside Spread & 3 & 3 & 2 & 2 & 2 & 4 & 2 \\
Spread at 10 units & 22 & 6 & 15 & 9 & 11 & 21 & 10 \\
Spread at 40 units & 75 & 25 & 60 & 58 & 55 & 75 & 60 \\
\hline
\end{tabular}

${ }^{\mathrm{a}}$ Spreads are shown as 1000 times the actual spreads. 